\title{
Comparative Haemolymph Biochemical Properties of Giant African Land Snail (Archachatina marginata) from Nigeria
}

\author{
AKINNUSI, F.A.O. ${ }^{1} \quad$ ONI, O.O. ${ }^{1} \quad$ ADEMOLU, K.O. ${ }^{2}$ \\ 1.Department of Agricultural Education, Federal College of Education, Abeokuta \\ 2.Department of Pure and Applied Zoology, Federal University of Agriculture, Abeokuta
}

\begin{abstract}
The Giant African Land Snails (GALS) is a very important micro livestock that is consumed widely within several regions in sub-Saharan Africa which differ in their vegetation types and climatic factors. Studies have shown that diet and stocking density influence properties of the snail haemolymph. This study examines the haemolymph biochemical properties of the land snail, (Archachatina marginata) from south-west (Ekiti, Lagos, Ogun, Ondo, Osun and Oyo). Organic (protein, lipids, glucose) and inorganic ( $\left.\mathrm{Na}, \mathrm{K}, \mathrm{Ca}, \mathrm{Cl}, \mathrm{PO}_{4}\right)$ composition of snails' haemolymph were determined by standard methods. Results showed that GALS from Oyo state had the highest lipids and glucose concentrations in the haemolymph while Ondo and Ekiti states recorded the least. Protein was the most abundant $(33.83 \mathrm{~g} / \mathrm{l}-49.37 \mathrm{~g})$ organic substance while lipids were the least $(23.93 \mathrm{mg} / \mathrm{dl}-33-93 \mathrm{mg} / \mathrm{dl})$. There were significant differences $(\mathrm{P}<0.05)$ in the concentrations of inorganic substances in the haemolymph across the six states. Snails from Oyo state recorded significant higher $(\mathrm{p}<0.05)$ concentrations of $\mathrm{Na}^{+}, \mathrm{Ca}^{2+}$ and $\mathrm{Cl}^{-}$than those of other states. Also, $\mathrm{Na}+$ and $\mathrm{Cl}$ - were the most common anions in snails' haemolymph from the six states. This current study concluded that snails from Oyo state had better haemolymph biochemical properties than other south west states of Nigeria.
\end{abstract}

DOI: $10.7176 / \mathrm{JBAH} / 10-12-02$

Publication date:June $30^{\text {th }} 2020$

\section{Introduction}

The Giant African Land Snail (GALS) (Archachatina marginata) occur commonly in high forest and small forest of derived savannah regions of West African (Yoloye, 1994). They are nocturnal animals and prefer moist, cool environment. Archachatina marginata like other land snails is active during the wet season and carries out reproductive activities (mating and oviposition) at this time (Akinnusi, 2004). During the dry season, it remains inactive under a rock, decomposing tree trunk and plant debris. This state of inactivity is called aestivation when the aperture of the shell is closed up with a thin whitish membrane called epihragm (Yoloye, 1994).

Snails are ectothermic and are influenced by various environmental factors such as temperature, relative humidity and rainfall. Haemolymph is a fliud analogous to the blood in vertebrates, that circulates the interior of the arthropod body. The blue colour of snail haemolymph reflects the presence of haemocyania-a cupper containing metallo-protein that is blue coloured when the former is oxygenated (South, 1992). Studies have shown that diet (Ademolu et al., 2007) and stocking density (Ademolu et al., 2009) influence properties of the snail haemolymph. Similarly, the physiological state of the snails can be detected through their haemolymoh composition (Akinloye and Olorode, 2000). Ademolu et al (2016) reported that A. marginata had low nutritive value during the raining season but high during the dry season. Also, rainfall had more influence on snail nutrients than other climatic factors.

Bamidele et al. (2018), carried out a survey of snails in five south western states of Nigeria and they observed that the haemolymph recorded higher concentration of $\mathrm{Na}+, \mathrm{Cl}-$, and $\mathrm{PO}_{4}{ }^{2}$ - than the flesh. Also, that snails from the five south western states of Nigeria are equally nutritious. However, there is need for a more comprehensive haemolymph biochemical survey that covers all the six states of southwest, Nigeria. Hence, the main thrust of this study is to determine the biochemical properties of GALS' haemolymph from the six western states of Nigeria.

\section{MATERIALS AND METHODS \\ Experimental Snails}

The six states in the south west of Nigeria (Ekiti, Lagos, Ogun, Ondo, Osun and Oyo) were divided into three main senatorial divisions making a total of 18 main towns. Each of these 18 towns were surveyed for $A$. marginata with the help of snail's gatherer from the wild. Twenty snails were purchased from each location and the haemolymph of the snails were collected immediately through the method described by Ademolu et al (2009). The haemolymph samples were kept in ice pack until further analysis in the laboratory.

\section{Chemical Analysis}

\section{(a) Organic substances}

Protein, glucose and lipids concentration in the snails haemolymph were assayed by method of Henry et al., (1997), Bunmniger (2005) and Grant et al (1999) respectively. 


\section{(b) Inorganic substances}

The haemolymph was digested using a mixture of per chloric acid and nitric acid (1:2 volume). The haemolymph's $\mathrm{Na}^{+}, \mathrm{K}^{+}, \mathrm{Ca}^{2+}, \mathrm{PO}_{4}{ }^{2+}$ and $\mathrm{Cl}^{-}$were determined by A.O.A.C (1990) method.

\section{Statistical analysis}

Data collected from the experiment were analyzed by One-way Analysis of Variance (ANOVA) and means separation was done by Students Newman-Kuel's (SNK) test.

\section{RESULTS}

The organic component of the snail's haemolymph from south western states, Nigeria is shown in Figure 1. There were significant differences in the concentrations of the organic substances in the snail's haemolymph. Snails from Ogun state recorded significantly higher protein in their haemolymph than other states. Snail from Oyo state recorded significantly higher $(\mathrm{p}<0.05)$ glucose and lipids concentrations than other states while snails from Ekiti state and Ondo state had the least in glucose and lipids respectively. Comparison of means revealed that protein was the most abundance organic substance $(33.93 \mathrm{~g} / \mathrm{c}-49.37 \mathrm{~g} / \mathrm{l})$ while lipids were the least.

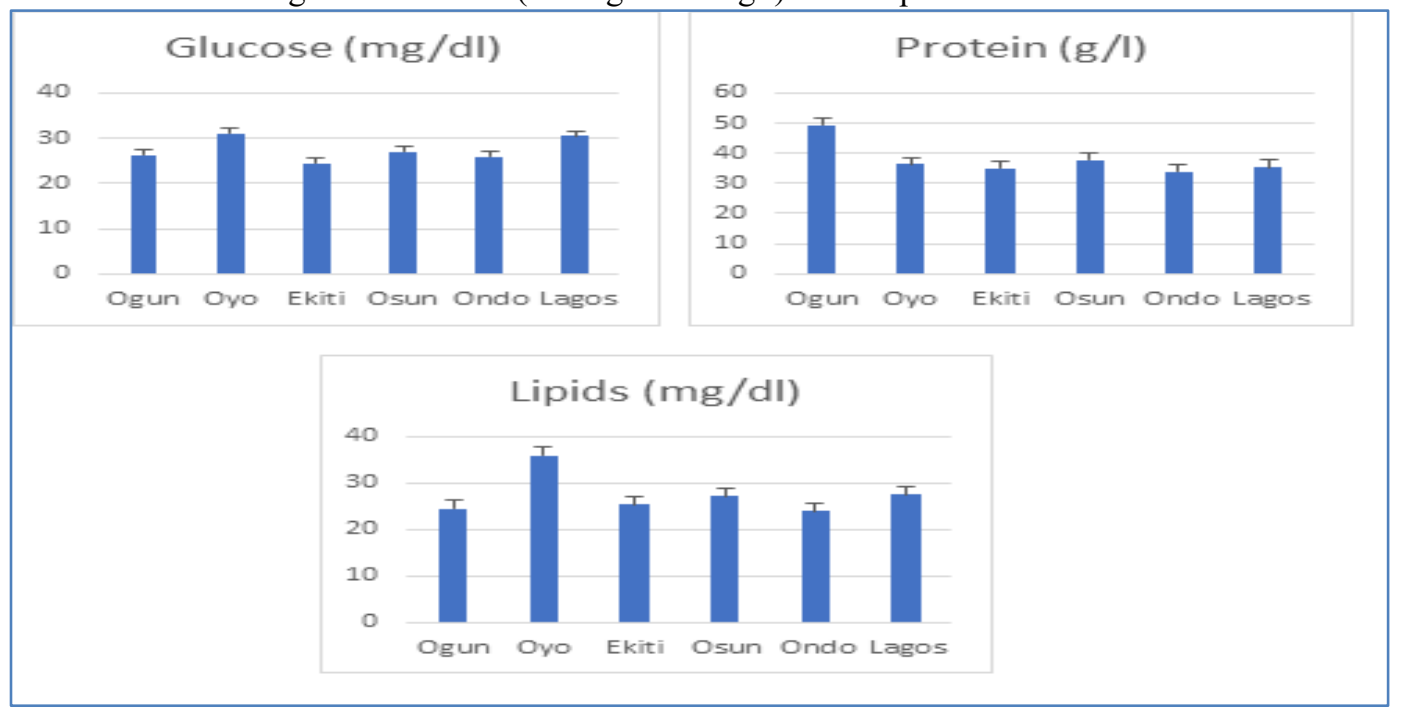

Figure 1: Haemolymph organic composition of snails from South Western states, Nigeria

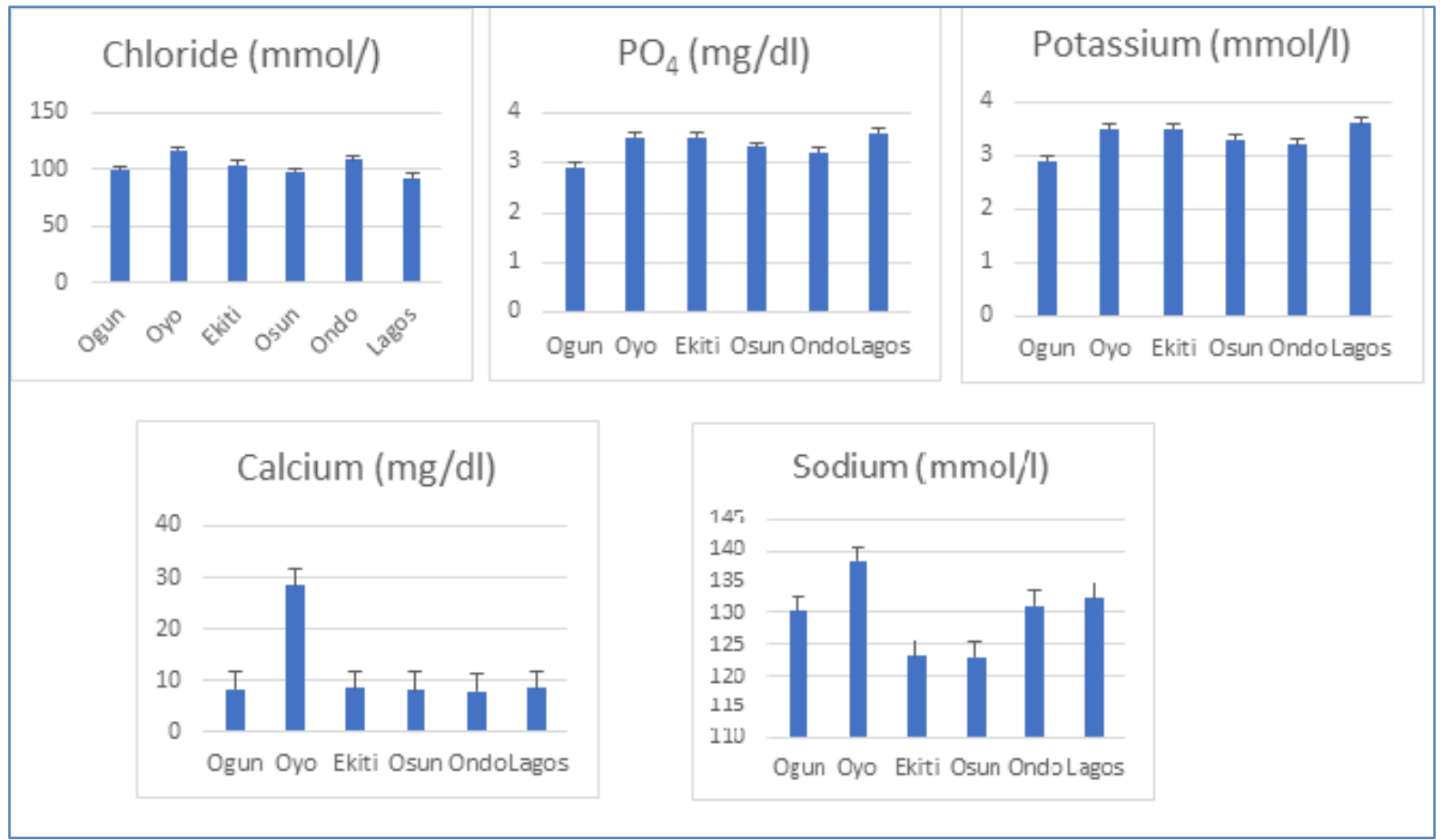

Figure 2: Haemolymph inorganic composition of snails from South Western states, Nigeria 
Figure 2 presents the concentrations of inorganic substances in the snail samples from south west states of Nigeria. $\mathrm{Na}+$ and $\mathrm{Cl}$ - had the highest concentrations in the haemolymph and snails from Oyo State had significantly higher $\mathrm{Cl}-, \mathrm{Ca} 2+$ and $\mathrm{Na}+$ concentrations than snails from other states. Potassium recorded the least concentration in the snails for all the 6 states $(2.87 \mathrm{mmol} / 1-3.6 \mathrm{mmol} / 1)$.

\section{DISCUSSION}

Snails are good source of protein which is the most abundant substance in the gastropods' haemolymph (Imevbore and Ademosun 1988, South, 1992). Since the snails used for this study were in adult stage, higher protein concentration in their haemolymph is not unexpected as protein are growth regulators and play significant role in reproduction (South, 1992) which is the main function of the adult snails. This high protein content in the haemolymph might possibly explain why musicians drink snails' haemolymph in order to soothe their throat as earlier mentioned by Amusan and Omidiji, (1998).

Lipids being observed to be the least concentrated haemolymph organic substance confirm the reports of other snail researchers (Akinnusi, 2004; Ademolu et al., 2007, Imevbore and Ademosun, 1988) that snails have less fat content and are good diet item for patients of heart related ailments.

Oyo state snails had significantly higher concentrations of glucose and lipids in their haemolymph. This agrees with the findings of Bamidele et al., (2018) who reported that Oyo state snails had significantly higher haemolymph protein, lipids and glucose, Oyo state had turned from being a tropical rain forest to a derived savannah where fewer trees are present (OYSG, 2015). Hence, higher energy substrates in the haemolymph might be a response to the less favourable conditions of the environment and means of adapting to the environment (Hainsworth, 1981). In contrast, less disturbed states of Ekiti and Ondo had low concentrations of these energy substrates, reflecting their comfort and less need for moving around due to harsh weather as the states are characterized by big, shady trees of normal tropical rainforest.

Sodium and chloride were the most abundance inorganic substances in the haemolymph of gastropods (South, 1992). The present study confirms this fact as $\mathrm{Na}+$ and $\mathrm{Cl}$ - recorded the highest concentrations of all the inorganic substances tested for. The presence of $\mathrm{Na}+$ and $\mathrm{Cl}$ - in the snail haemolymph disagrees with the report of Ogunsanmi et al., (2003) that $A$ marginata lacks sodium and chloride in its haemolymph $\mathrm{Na}+$ and $\mathrm{Cl}$ - are highly essential for osmotic balance of the snails and are likewise needed for nervous communication (Odiete, 1999). In conclusion, haemolymph biochemical properties of GALS from the six south western states of Nigeria differ significantly with the Oyo state recording higher values than other states due to varying environmental factors.

\section{REFERENCES}

Ademolu, K.O, Idowu, A.B and Mafiana, C.F and Osinowo, O.A. (2007). Performance, proximate and mineral analysis of African Giant Land Snail (Archachatina marginata) fed on different nitrogen sources.Tropical veterinarian 25(4):124-131.

Ademolu, K.O;Idowu, A.B and Jayeola, O.A (2009). Changes in haemolymph biochemical values during different growth phases in African Giant Land Snail (Archachatina marginata) Swainson. Nigerian Journal of Animal Production 36 (1): 161-166.

Ademolu, K.O., Bamidele, J.A. and Esue, S. (2014). Seasonal variations in the nutrient composition of Giant African Land Snail (Archachatina marginata). Proceedings of the $3^{\text {rd }}$ International Conference of Research Network on Giant African Land Snails (NetGALS) held on $1^{\text {st }}-4^{\text {th }}$ of June, 2014. Pp 111-113.

Akinloye, O.A. and Olorode, O. (2000). Effect of different feeding condition on performance, haemolymph biochemical and mineral value of Giant African Land Snail (Archachatina marginata). Journal of Agriculture and Environment, 1 (1), 143-147.

Akinnusi, O. (2002). Introduction to Snails and Snail Farming. Triolas Publishing Company, Abeokuta. 70pp

Amusan, J.A. and Omidiji, M.O (1998). Edible land snails. A technical guide to snails farming in the tropics. Verital printers, Ibadan, pp 17-23

A.O.A.C. (1990). Association of Official Analytical Chemists (Ed. Horwitz) $13^{\text {th }}$ edn, Washington, D.C. 1141pp

Bamidele, J.A., Ademolu, K.O., Idowu, A.B., Aladesida, A.A., and Oladele, A.O (2018). Biochemical and nutritional composition of Giant African Land Snail (Archachatina marginata) from southwest, Nigeria. Pertanika. J. Trop. Agric. 41(1):127-136.

Baumniger, R.N (1974). Analytical Chemistry. Cambridge Press, London Pp83-85

Grant, G.H. (1987). Amino acids and Protein: Fundamental of clinical chemistry: Fundamentals of clinical chemistry. WB Sander Company, Philadelphia, U.S.A. Pp 326-329.

Hainsworth, F.R. (1981). Animal Physiology. Adaptation in function. Addison-wesley Publishing company, London, $669 \mathrm{pp}$.

Henry, R.J; Canon D.C and Winkalman, J.W (1974). Clinical Chemistry; Principle and Technique $2^{\text {nd }}$ ed, Harper and Row Pubishers, New York, Pp 54-56..

Imevbore, S.A. and Ademosun, A. (1988). The nutritive value of African Giant Land Snail. (Archachatina 
marginata). Journal of Animal Production Research 8(2): 76-87.

Odiete, W.O. (1999). Basic Animal Physiology, Diversified Resources Ltd, Lagos, Nigeria. 257pp

Ogunsanmi, A.O., Taiwo, V.O. and Akintomide, T.O. (2003). Haemolymph biochemical parameters of African Giant Land Snail (Achatina achitina) and the big black snail (Archachatina marginata). Trop. Vet. 21 (2): 43-48

OYSG (2015). Weather and Climate. Oyo State Government. Retrieved from http://www.oyostate.gov.ng/aboutoyo-state/the-state

South, A. (1992). Terrestrial Slugs: Biology, ecology and control. Chapman and Hall, U.S.A pp 66-101

Yoloye, V.L (1994): Basic Invertebrate Zoology $3^{\text {rd }}$ Edition pp. 139-145 